\title{
Eugénia Melo e Castro e o Clube da Esquina: o sonho de uma canção Iuso-brasileira-múndi
}

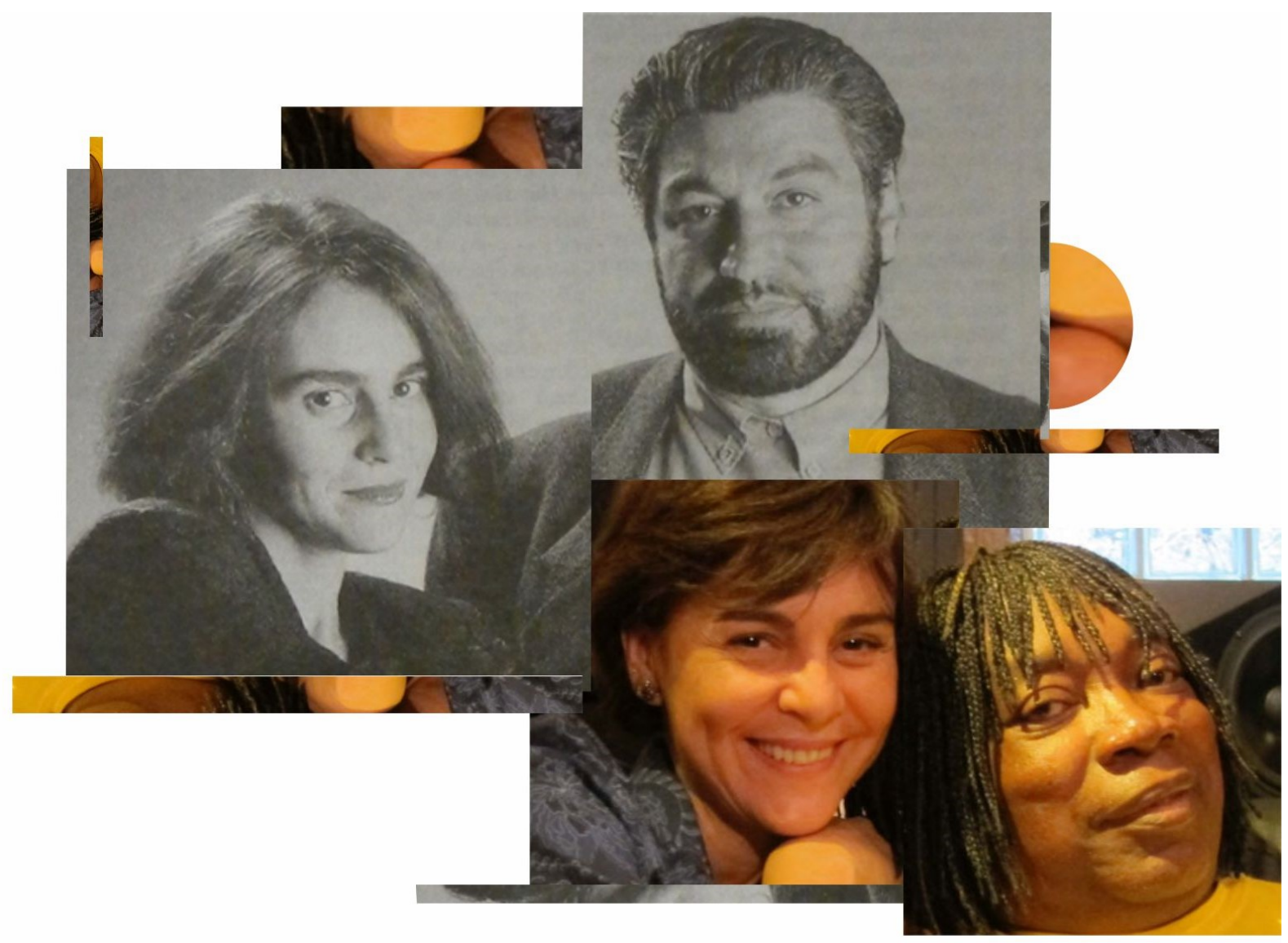

Eugénia Melo e Castro, Milton Nascimento e

\section{Mateus de Andrade Pacheco}

Doutor em História pela Universidade de Brasília (UnB). Coorganizador do livro Sinfonia em prosa: diálogos da história com a música. São Paulo: Intermeios, 2013. mateusandpac@gmail.com 


\section{Eugénia Melo e Castro e o Clube da Esquina: o sonho de uma canção luso-brasileira-múndi ${ }^{1}$}

Eugénia Melo e Castro and Clube da Esquina: the dream of a Luso-Brazilian world song

\section{Mateus de Andrade Pacheco}

\begin{abstract}
RESUMO
Durante os encontros da cantoracompositora portuguesa Eugénia Melo e Castro com os músicos brasileiros Wagner Tiso, Milton Nascimento e Novelli, no princípio da década de 1980, floresce um animado debate em torno de uma busca conjunta de linguagens desafiadoras de padrões musicais reconhecidos e consagrados artisticamente. Em tal cenário, os artistas se sentem estimulados a se reinventar, numa convergência de ritmos, interpretações e dicções, desenhando reflexões sobre uma música ancorada em sonoridades plurais e no sentimento de pertença ao mundo. Na medida em que se intensificam as discussões, outras presenças artísticas são convocadas, tais como as dos portugueses Sérgio Godinho e do grupo Trovante, além de vozes brasileiras, trazidas à cena por alguma lembrança anedótica, algum detalhe musical ou até mesmo alguma sonoridade familiar que invade alguma criação momentânea.
\end{abstract}

PALAVRAS-CHAVE: Clube da Esquina; Eugénia Melo e Castro; fronteiras.

\begin{abstract}
During Eugénia Melo e Castro's - Portuguese singer and songwriter - meetings with the Brazilian musicians Wagner Tiso, Milton Nascimento, and Novel$l i$, in the early 80's, a lively debate flourishes around a joint search for challenging speeches from highly regarded and artistically known musical patterns. In that scenario, the artists feel encouraged to reinvent themselves, in a confluence of rhythms, interpretations and dictions, drawing reflections on music based on plural sounds and a feeling of world belonging. As discussions grow heated, other artistic presences are invited, such as the Portuguese artists Sérgio Godinho and Trovante's group, in addition to Brazilian voices, brought to the scene by some sort of anecdotal memory, musical detail or even a familiar sound that invades a transitory creation.
\end{abstract}

KEYWORDS: Clube da Esquina; Eugénia Melo e Castro; borders.

\footnotetext{
${ }^{1}$ Este artigo é um desdobramento de pesquisa de pós-doutorado desenvolvida junto ao Departamento de Sociologia da Faculdade de Letras da Universidade do Porto, entre 2015 e 2016, para a qual contei com o apoio de bolsa concedida pela Capes. Agradeço à Paula Guerra, minha supervisora, pelas contribuições nessa experiência e pelo entusiasmo com que conduz os diálogos acadêmicos. Estendo esse agradecimento à Eleonora Zicari, Leandro Mendanha, Maria Abília e Mayara, importantes interlocutores nesse processo. Agradeço também à Luiza, que tão bem me apresentou o acervo da Hemeroteca de Lisboa.
} 
Abril de 1980. Jornais portugueses destacavam a primeira passagem de Milton Nascimento por Lisboa para única apresentação no palco do Coliseu dos Recreios. Nas semanas que antecipavam a grande noite, veículos como o Diário de Notícias e o semanário Se7e reservariam importante espaço para apresentar o artista brasileiro. Naquela virada da década de 1970 para a de 1980, a música brasileira alçaria voo largo no meio artístico lusitano. A porta de entrada seria a televisão, mediante o sucesso das telenovelas da Rede Globo junto ao público português. É evidente que não podemos resumir o alcance da música brasileira em Portugal a esse fator. No entanto, também seria um equívoco ignorá-lo. A partir dessa via de acesso privilegiadamente massiva, outros espaços de divulgação, como jornais e revistas, e especialmente o rádio, reverberariam a trilha sonora das novelas a um público cada vez mais amplo, popularizando, de fato, a canção brasileira em solo português. Assim, já era possível acompanhar programas como o "Cantores do Rádio", dedicado exclusivamente à MPB e apresentado por José Nuno Martins. Nele, ouviam-se as novidades do momento, entrevistas com grandes nomes da MPB e até era possível saborear comentários e pensamentos de participantes como o escritor brasileiro João Ubaldo Ribeiro, conhecido do público português por sua obra literária e pelas crônicas feitas especialmente para o Se7e. Observa-se, portanto, uma curiosidade maior pela cultura brasileira, a partir do contato com os temas abordados nas novelas, com as imagens e conflitos ali apresentados, enfim com os costumes em geral presentes na narrativa. Vale dizer, a recepção da arte brasileira se atualiza, a partir do acesso a informações contemporâneas que habilitam o público a se apropriar de uma realidade estrangeira cada dia mais familiar. No circuito da comunicação de massa, críticos abalizados emitem comentários, colunistas contam anedotas e dão informações extras sobre os artistas, ou seja, mais e mais detalhes vão se juntando a outros, de modo a inserir o artista numa galeria de famosos ou - para não dizer tanto - num rol de nomes familiares e conhecidos dos chamados formadores de opinião.

Retomando o semanário português $S e 7 e$, este se dedicava ao campo das artes em geral, concedendo relevante espaço para variadas tendências musicais da atualidade, incluindo a música brasileira. Ao folhearmos números do Se7e, deparamos com grande diversidade de representantes da MPB: Elis Regina, Gal Costa, Joyce, Paulinho da Viola, Chico Buarque, Maria Bethânia, Milton Nascimento, Nana Caymmi, João Bosco, Ivan Lins, Edu Lobo, Egberto Gismonti, Baden Powell, Caetano Veloso, Tânia Mara, Gilberto Gil, Elba Ramalho, Fafá de Belém, e por aí vai. O mesmo fenômeno povoaria outros veículos, como se pode observar pela revista especializada Mundo da Canção. A presença de nomes vinculados a MPB tornou-se constante em Portugal, fosse através de shows em casas como o Coliseu, fosse em importantes eventos como o Festival do Se7e e a Festa do Avante!, promovida pelo Partido Comunista. Eventos ao vivo ganhavam páginas de jornais e revistas, e assim se vê que um meio ia alimentando o outro, consolidando a imagem do artista em cenário internacional. Malgrado a agitação em torno da MPB através desses veículos, faz-se mister reconhecer também que, justamente nesse espaço privilegiado de 
divulgação, constatamos relatos de críticos desgostosos com algumas lacunas, imprecisões nas informações, muitas vezes decorrentes de mera desatualização no tocante ao trabalho de músicos brasileiros. Noutras palavras, não se conhecia tanto quanto se imaginava, ou, pelo menos, se desejava, do trabalho atual desses artistas, especialmente se considerarmos a efervescência de uma época em que o Brasil buscava diálogos com outros países pela via musical, impulsionado pelos avanços no setor de comunicações e pelo crescimento da indústria fonográfica mundo afora.

Assim, no momento em que Milton Nascimento desembarcava em Portugal, matérias e críticas jornalísticas destacavam a qualidade de sua música, suas parcerias e gravações com legendas do jazz norte-americano - como Wayne Shorter e Herbie Hancock -, além do sucesso junto à crítica estrangeira. No Se7e, por exemplo, constava sobre o seu último disco gravado nos Estados Unidos, o Journey to dawn, em 1978: "coloca Milton na relação dos melhores do ano da revista Downbeat, superando nomes como Elton John e Frank Sinatra" ${ }^{2}$ Noutro texto destacava-se o sucesso da temporada em Paris: vinte dias de casa cheia no Théâtre de la Ville. ${ }^{3}$ Milton Nascimento transpunha, assim, as fronteiras brasileiras para começar a se tornar um nome de relevo internacional.

Entretanto, e justamente por conta do êxito de tal investimento, rascunhava-se a indagação: como um nome daquela envergadura artística ainda era quase desconhecido do público português? Em texto sobre o show de Milton no Coliseu dos Recreios, James Anhanguera, crítico musical brasileiro e colaborador do Diário de Notícias, tentava alinhavar uma explicação:

Quem não esteve no Coliseu domingo à noite perdeu uma das grandes manifestações de calor e beleza do público português, talvez já ambientado e embalado pelos festejos de 25 de abril. E por quem? Pelo cantor que possui a mais bela voz de homem que se pode ouvir nos dias de hoje, cuja obra, entretanto, nos parecia, até domingo quase desconhecida em Portugal (apenas quatro dos seus discos - dois deles gravados nos EUA - foram aqui editados, tendo alguns sido importados, poucas cópias - nenhum posterior a 1974). Mas quem ali estava parecia saber muito bem ao que ia: para rezar os mil tons da era miltoniana. ${ }^{4}$

Embora o público português demonstrasse desconhecimento a respeito de discos considerados fundamentais, tais como Clube da Esquina (1972), Milagre dos peixes (1973), Minas (1975) e Geraes (1976), o show foi muito bem recebido pelo crítico, que identificou na reação apaixonada de um público de cerca de 5 mil pessoas uma verdadeira aclamação de um artista consagrado. O entusiasmo daquela noite entremearia as críticas do show, que aplaudiam o caráter universal de uma música inspirada em diálogos musicais desde o trabalho de composição e arrematada no palco de maneira singular, num grande congraçamento musical entre cantor, músicos e público, como se o processo de composição não terminasse nunca, renovando-se a cada show. Assim, o cantor convertia o palco em lugar de encontro consigo mesmo, com os músicos e com

\footnotetext{
${ }^{2}$ Nome grande da MPB. Milton Nascimento “ao vivo" no Coliseu. Se7e, Lisboa, 22 abr. 1980, p. 6.

${ }^{3}$ Cf. MACEDO, António de. Milton Nascimento no Coliseu. Se7e, Lisboa, 29 abr. 1980, p. 24.

${ }^{4}$ ANHANGUERA, James. A travessia de Milton. Diário de Notícias, Lisboa, 29 abr. 1980, p. 11.
} 
o público, numa retumbante celebração à vida, saboreada em misturas sonoras que tocavam o mais íntimo de cada um ali presente, e ao mesmo tempo unia a todos numa fraternidade musical que agora passava a compartilhar códigos e memórias para outras experiências musicais.

Retomando o artigo de Anhanguera no Se7e, chama ainda a atenção, relativamente à reação do público, o trecho em que é dito que o espetáculo foi "uma das grandes manifestações de calor e beleza do público português". Trata-se, bem se vê, de um público qualificado, que, em detrimento de um investimento insatisfatório da gravadora de Milton Nascimento no lançamento de discos do cantor naquele país, mostrava-se interessado pelo artista a ponto de comparecer ao show consciente do que veria. É um público que busca o artista em vários veículos e não perde a oportunidade de se atualizar com o seu trabalho quando se vê premiado pela oportunidade de presenciar o espetáculo ao vivo.

A crítica destacaria ainda o grupo que acompanhava o cantorcompositor e o caráter livre daquela música, aparentemente vizinha do jazz:

Wagner Tiso é o "maestro" do grupo, no olhar, no pisar das teclas, em harmonias dissonantes, na elaboração de uma atmosfera sonora ritmicamente "marcada" pelas intervenções aparentemente a "destempo" de Luís Alves [baixista] e Roberto Silva [baterista] a quem compete, mais do que a ninguém, sublinhar o tempo inesperado do cantar de Milton. Toninho Horta é, neste contexto, o músico de trabalho mais discreto. [...] ele é, no entanto, o instrumentista que "cobre" todos os espaços deixados em aberto pelos seus companheiros, o guitarrista de supertécnica e de conhecimentos profundos que alia o trabalho oficinal a uma autenticidade criativa difícil de escutar nos músicos de formação ocidental. ${ }^{5}$

Aqui a análise do crítico recai sobre a parte instrumental do show - e não poderia passar em branco tal abordagem, uma vez que, como dito, a canção de Milton Nascimento nasce de vários encontros afetivo-musicais e, inspirada pelo virtuosismo dos músicos, sofistica-se na harmonia, para finalmente acomodar aquela voz singular a ditar o tom da canção. Sem exagero, pode-se dizer que a voz buscaria traduzir o som, ajuntando-lhe palavras ritmicamente, mesclando-se com o acompanhamento dos instrumentos por meio de vocalises, em falsetes ou notas graves, num abre-alas para uma procissão de muitas vozes e sons que se avolumam. É realmente um apelo irrecusável ao público a se juntar àquele movimento ou pelo menos a se deixar levar por ele.

O recorte registra memórias daquele show. Durante a década de 1980, Milton Nascimento investiria de maneira mais incisiva numa carreira internacional, sendo constantes suas aparições em palcos de distintos países. ${ }^{6}$ Portugal passaria a integrar o itinerário de suas turnês. A partir dessa primeira apresentação, seus discos seriam distribuídos de forma mais eficaz. Logo após esse show, por exemplo, já seria anunciada a chegada do Journey to dawn e de Milagre dos peixes ao vivo, disco emblemático e aclamado como um dos principais do artista pela crítica portuguesa.

\footnotetext{
${ }^{5}$ MACEDO, António de. Milton Nascimento no Coliseu. Se7e, op. cit., p. 24.

${ }^{6}$ Cf. DUARTE, Maria Dolores Pires do Rio. Travessia: a vida de Milton Nascimento. Rio de Janeiro: Record, 2006.
} 
Aquela noite no Coliseu também chamaria a atenção para o trabalho de Wagner Tiso, praticamente desconhecido em Portugal, e para aquela trupe de grandes instrumentistas, ou seja, para o Clube da Esquina, expressão que nomeia a agremiação de artistas que se reuniu ao redor de Milton Nascimento ao longo dos anos 1970 e que forjou linguagens musicais de tonalidades experimentais e coletivas, inovadoras pela maneira de se apropriar de gêneros diversos e amalgamá-los.7 Naqueles jornais portugueses onde a MPB era aclamada por sua criatividade e diversidade, ecoava agora essa vertente musical de feição universal.

As idas e vindas de artistas brasileiros a Portugal e de artistas portugueses ao Brasil abririam espaço para intercâmbios culturais. Nos entremeios de viagens, conheciam-se nomes locais, trocavam-se ideias, teciam-se laços e fazia-se muito som. Ao observarmos materiais jornalísticos sobre passagens de artistas como Milton Nascimento e Wagner Tiso por terras lusitanas, contemplamos seus diálogos com nomes da cena local, tais como Eugénia Melo e Castro e Sérgio Godinho. E ainda notamos como a sonoridade do Clube da Esquina surge como linguagem possível para esses diálogos. No espaço desse artigo, destacaremos essas trocas sonoras, que desafiam fronteiras e forjam lugar para expressar a criatividade, onde a música é motivo de reconhecimento e surpresa.

\section{Do lado de lá das fronteiras: o Clube da Esquina como linguagem inovadora e lugar de encontro}

Aquele show memorável de Milton Nascimento e do pessoal do Clube da Esquina ficou gravado nas memórias de Eugénia Melo e Castro, cantora e compositora portuguesa que fez da ponte com a música brasileira a principal via de expressão de sua arte. Em meio àquela plateia ávida pela música de Milton Nascimento, a artista iniciante buscava contatar Wagner Tiso para ser seu arranjador. Ora, o que não foi possível naquele dia inspirou-a a viajar ao Brasil, onde finalmente obteve a resposta positiva do maestro para conceber os arranjos de Terra de mel, disco que marcaria a estreia da cantora no mercado discográfico em 1982. A história da jovem audaciosa que chegou à porta de Wagner Tiso com uma fita cassete na mão e muitas ideias na cabeça virou notícia quando o disco foi lançado. Aliás, a presença de Wagner Tiso seria um dos fatores que impulsionariam a gravadora a investir em Terra de mel. A partir daí, Eugénia Melo e Castro teria estúdio liberado para, junto com músicos do Brasil e de Portugal, iniciar sua viagem musical madrugada afora.

Nos percursos dessa pesquisa, criou-se oportunidade para entrevistar Eugénia Melo e Castro, que aqui recorda sobre seu interesse pela sonoridade clube-esquinista e sobre sua escolha por Wagner Tiso:

Eu tive acesso também, muito precoce, aos discos do Wagner ainda na Matança do porco do Som Imaginário. Quando eles começaram a gravar discos, eu acompanhei. Não sei, eu acho que foi identificação. Houve um disco que foi absolutamente definitivo, que foi o Native dancer, que o Wagner foi gravar a Los Angeles com Wayne

${ }^{7}$ Cf. PACHECO, Mateus de Andrade. Milton Nascimento: num canto do mundo, o conto do Brasil. Tese (Doutorado em História) - UnB, Brasília, 2014. 
Shorter e com o Milton e com convidados, que foi o Robertinho e foi mais uma trupe e tal. E que eu acho que até hoje é um dos meus discos... se me disserem assim, cinco discos de cabeceira, o Native dancer é um dos discos de cabeceira. Milagre dos peixes, Minas, o Geraes... e tudo isso são discos que têm uma importância para mim porque havia ali também uma influência enorme de imensas coisas que se passavam no mundo. E que o Milton absorvia e transformava e transcodificava. E que o Wagner fazia os arranjos e fazia aquelas coisas extraordinárias. Portanto, era uma coisa toda muito espontânea, mas ao mesmo tempo muito influenciada e muito original. Muito boa. Uma qualidade, assim, indiscutível em qualquer século, em qualquer momento, atemporal. E isso tocava-me bastante, porque era uma coisa pronta. Não havia ali um "ah, vou fazer para ver como é". Era uma coisa que se apresentava concluída. Embora eles estivessem sempre em evolução. Mas era uma coisa sólida. Uma coisa que a gente ouvia e "ah, o que é isto?". Depois Beto Guedes, depois a Página do relâmpago elétrico, depois não sei que, os Borges. Toda aquela coisa, que era uma coisa, assim, fascinante. ${ }^{8}$

O nome de Wagner Tiso surge como alternativa para uma artista que ansiava por uma linguagem musical inovadora, sintonizada com o que havia de mais atual no cenário internacional. A interação da música de Milton Nascimento e Wagner Tiso com o jazz e o rock interessava, portanto, à cantoracompositora, que tinha nesses gêneros referências de suas primeiras audições. Mas, para além disso, importava mesmo era a apropriação musical operada pelos artistas brasileiros no contato com esses gêneros musicais ao assimilá-los ao caldo musical do Clube. O espanto vinha de um som que, de ancestral e exótico, fluía para temáticas mais urbanas - e já o sertão era o asfalto, o asfalto era o sertão, o quintal de casa era a rua, e esta se abria para um mundo de possibilidades. Sem nenhum itinerário especial, esses bardos de espírito viajante e pesquisador inaugurariam linguagens em descobertas feitas pelo caminho, promovendo releituras de antigos temas musicais, de antigas peças do cancioneiro popular, de canções consagradas mundialmente, algumas das quais gravadas pelos próprios artistas em versões para o português, o que indicaria, podemos assim dizer, uma canção itinerante, ou uma forma de compor coletiva e em movimento, sempre agregando algum detalhe novo e absorvendo-o musicalmente.

A singularidade desse procedimento recai no jogo da interseção de várias épocas. Vale dizer: passado, presente e futuro em diálogo, complementando-se como instâncias de reflexão, interpretação e criação. Visitas ao próprio repertório, letras acrescidas a peças instrumentais já gravadas em álbuns consagrados, tudo isso sinalizava um estilo de compor no recompor-se, no repensar-se; uma forma de se perpetuar, de manter vivo o menino, o jovem, o homem maduro, de conservar o espírito irrequieto, numa eterna busca de si mesmo, atiçando no público o desejo de fazer o mesmo, de também sair em viagem, garimpando pequenas joias de um tesouro precioso, generosamente distribuído ao longo do tempo - o tesouro da história pessoal de cada um, em âmbito individual e coletivo, ao som de uma trilha sonora atemporal e universal.

\footnotetext{
${ }^{8}$ Eugénia Melo e Castro em entrevista concedida ao autor. Lisboa, 5 abr. 2016. Dela participou como colaborador o pesquisador Leandro Mendanha e Silva.
} 
Essa sonoridade peculiar é que chamaria a atenção do público e de artistas como Eugénia Melo e Castro. Mesmo as parcerias e diálogos de Milton Nascimento com grandes nomes do jazz eram firmadas pelo caráter inovador de um modelo de música que não se enquadraria nesse ou naquele gênero. Se bem pensarmos, em discos como o Native dancer, citado por Eugénia Melo e Castro, o que se tem é uma parceria frutífera, onde a música de Milton e de sua trupe dá novo respiro ao universo do jazz e, ao mesmo tempo, o som de Wayne Shorter confere uma coloração distinta à linguagem miltoniana. Aqui a música surge como espaço de interação e troca. Nessa linha, o jazz é contemplado como postura que se edifica através da liberdade. ${ }^{9}$

"Sou do mundo, sou Minas Gerais"10, verso gravado na memória dos admiradores da obra do Clube da Esquina, repercute o percurso feito por aquela música de sotaque universal: rock, jazz, música clássica, o rock progressivo, referências da cultura popular, tudo era ingrediente para aquele caldeirão sonoro. A maneira de amalgamar esses sotaques diversos chamaria a atenção para o aspecto instrumental da obra de Milton Nascimento e Wagner Tiso. Os trabalhos dos artistas envolvidos no Clube da Esquina ficaram reconhecidos justamente pelas harmonias complexas e inusitadas, pelo clima de produção coletiva, onde cada músico enriquecia aquelas peças numa interação ativa e espontânea. Além disso, a própria poética dos versos de nomes como Márcio Borges, Fernando Brant, Ronaldo Bastos e Murilo Antunes reverberava o esmero de todo o trabalho de composição, num jeito de fazer letra em diálogo com o refinamento dos arranjos, com o virtuosismo dos músicos, como se o compositor antevisse espaços de discussão também com a parte instrumental. Em artigo que se debruça sobre as inovações e particularidades desse agrupamento de artistas, o pesquisador Ivan Vilela afirma: “Com o Clube da Esquina a canção passou a ser submissa à roupagem que lhe era colocada, o arranjo. Em nenhum momento pensara-se em agasalhar a canção da maneira como foi feita por eles". ${ }^{11}$ Traçavam-se, dessa forma, rotas para o experimentalismo, longe dos modismos e propícias à criatividade. A importância do elemento instrumental seria fundamental nesse exercício. Em afirmação pronunciada numa entrevista concedida ao Se7e na década de 1980, Wagner Tiso colaboraria para essa constatação: “Qualquer movimento que apareça terá necessariamente que partir da música instrumental. Tem sido sempre ela a abrir novos horizontes". ${ }^{12}$

A aglutinação de referências musicais diversas e o cuidado com os arranjos moveriam o diálogo de Eugénia Melo e Castro com aquele agrupamento de artistas. A admiração e o diálogo com Wagner Tiso e Milton Nascimento logo se estenderiam a outros nomes importantes, tais como Ronaldo Bastos (com quem foi casada), Beto Guedes, os Borges, Novelli, Toninho Horta, Túlio Mourão etc. Na verdade, a obra de Eugénia Melo e Castro buscaria ampla aproximação com a música brasileira, sendo vários os trabalhos com a presen-

\footnotetext{
${ }^{9}$ Cf. PACHECO, Mateus de Andrade, op. cit.

10 "Para Lennon e McCartney" (Lô Borges, Márcio Borges e Fernando Brant), Milton Nascimento. LP Milton, EMI-Odeon, 1970.

11 VILELA, Ivan. Nada ficou como antes. Revista USP, n. 87, São Paulo, set.-nov. 2010, p. 24.

12 TISO, Wagner apud DUARTE, Pedro. Wagner Tiso ao Se7e: “adorei trabalhar com Geninha”. Se7e, Lisboa, 12 ago. 1982 , p. 16.
} 
ça de grandes nomes da MPB, como Ney Matogrosso, Chico Buarque, Caetano Veloso, Tom Jobim, Egberto Gismonti, Adriana Calcanhoto etc.

\section{Terra de mel: na ponta do abismo, entre Portugal e Brasil, o mundo}

Apaixonada por música desde a infância, Eugénia teve acesso à música brasileira bem cedo, através de seu pai, Ernesto Manuel Geraldes de Melo e Castro, poeta e ensaísta que constantemente visitava o Brasil para encontros de poesia concretista. A cada viagem, dezenas de discos indicados por amigos brasileiros desembarcavam na casa dos Melo e Castro. Espontaneamente, Eugénia ia se informando e descobrindo o Brasil através daqueles discos. Teve, inclusive, acesso a álbuns raros, como um disco que destaca como também de cabeceira, o Imyra Tayra Ipy, Taiguara, do cantor-compositor Taiguara, obra censurada logo após o lançamento no Brasil em 1976. A assinatura de Wagner Tiso na lista de legendas da música brasileira reunidas naquele álbum conceitual foi mais um alerta para o nome do arranjador em trabalho de tamanha envergadura. ${ }^{13}$

Deve-se destacar que, naquela virada dos anos 1960 para os 1970, quando Eugénia Melo e Castro começava suas audições de música brasileira, a MPB ainda não tinha a entrada que experimentou em Portugal na década de 1980. Embora fosse conhecida por algumas parcelas do público, a distribuição de discos de nomes vinculados à sigla ainda era escassa e mesmo a presença desses artistas através de shows era esporádica. No entanto, vivências como a da cantora-compositora portuguesa nos colocam diante de maneiras alternativas de circulação musical: fosse por meio de parentes, imigrantes ou de amigos, aquela música chegava aos ouvidos de uns e outros. Ainda mais daqueles que se reuniam em torno da vitrola para compartilhar e digerir descobertas musicais em tempos em que as audições coletivas faziam parte do cotidiano. Assim, quando a música de Milton Nascimento e Wagner Tiso ainda era praticamente ignorada pelo público português, Eugénia já se aprofundava na sonoridade clube-esquinista através de álbuns ainda mais incomuns, como os do Som Imaginário ${ }^{14}$, grupo formado para acompanhar Milton Nascimento nas turnês e que, depois, alçou voo próprio.

Em matéria publicada em fevereiro de 1982, Terra de mel é apresentado como grande revelação do ano pelo Se7e. As canções do disco foram criadas por meio de parcerias de Eugénia Melo e Castro, que assina praticamente todas as letras, com músicos brasileiros conhecidos nas andanças pela rica cena musical de Lisboa, como o compositor e guitarrista Yório Gonçalves e Kleiton Ramil, que inclusive compôs o sucesso "Vira-virou" na casa da cantora e ainda atuou no disco tocando guitarra e violino. Do Brasil ainda viriam Kledir Ramil, outro colaborador em composição com Eugénia que também atuaria na viola ovation e percussão. E Wagner Tiso, que além de assinar os arranjos e a

\footnotetext{
${ }^{13}$ A respeito do disco e obra de Taiguara, ver PACHECO, Maria Abília de Andrade. Taiguara: a volta do pássaro ameríndio (1980-1996). Dissertação (Mestrado em História) - UnB, Brasília, 2012.

${ }^{14}$ A primeira formação do Som Imaginário tinha Wagner Tiso no piano, Luiz Alves no baixo, Robertinho Silva na bateria, Tavito na viola de 12 cordas, o Fredera na guitarra, Zé Rodrix na voz e órgão e Laudir Oliveira na percussão. Mas outros nomes passariam pelo grupo em formações posteriores, como Naná Vasconcelos, Nivaldo Ornelas, Toninho Horta, Jamil Joanes e Paulinho Braga. Cf. SILVA, Beatriz Coelho da. Wagner Tiso: som, imagem, ação. São Paulo: Imprensa Oficial do Estado de São Paulo, 2009.
} 
direção musical, tocou piano, acordeão e órgão. De Portugal, convocariam nomes reconhecidos pela criatividade, tais como Luís Caldeira, que ficou por conta das flautas, Luís Duarte, no baixo, e Zé Martins, bateria, percussão e passaredo. A respeito do Terra de mel, António Duarte escreveria em tom de crônica no Se7e: "Deixa-me dizer às pessoas que me leem que tu não existes. Que talvez sejas uma brisa de África imigrada nos Brasis a cantar em letra de Pessoa a música dos mágicos. Deixa-me não escrever sobre música hoje. Afinal, Wagner Tiso é um mago de história de fadas e um artífice de cores. Descreve círculos abertos e rápidos no pentagrama. Afinal a tua voz é um feitiço. Semeia o sonho, o fascínio, a paixão" ${ }^{15}$

Naquele primeiro passo, a música de Eugénia é celebrada por se erguer como lugar de encontro e trazer um quê distinto à música portuguesa. Terra de mel iça uma teia intimista e quente onde a voz daquela artista e daqueles instrumentos emaranham-se e arremessam-se, numa curtição sonora que exala uma atmosfera contemplativa. Ali, descortinam viagens, tema frequente nos versos de Eugénia, que faz da metáfora, embarcação. "Voltas ao cais depois como é/ tens um barco aqui mesmo ao pé/ descobre, corre, encobre, cobre terra em terra ser/ descobre terras, desterras eras, não eras, és". ${ }^{16}$ Os versos, abrigados num ambiente lisérgico, trazem um ar de Clube da Esquina, onde a metáfora também se constitui em assinatura poética e a viagem é tema recorrente. Compartilham, assim, maneiras de ver e sentir. Cada verso de Eugénia se entranha na movimentação daquele som. Ali, busca-se o entremeio, montase a fronteira, meio de encontro, seja ele no espaço, no tempo, na subjetividade de sentimentos ou da própria linguagem musical: “No meio daquele reflexo de água/ no centro de um repuxo de vento/ parada numa corrente de mar/ estou dentro do que quero estar" ${ }^{\prime 17}$ Faz recordar as palavras de Michel de Certeau, quando afirma: "Lugar terceiro, jogo de interações e de entrevistas, a fronteira é como um vácuo, símbolo narrativo de intercâmbios e encontros". ${ }^{18}$ E quando não cabem palavras, povoa-se o silêncio de puro som, como na faixa que abre o disco, o tema instrumental "Beco do Tiso" (Kleiton Ramil), no qual a liberdade já é sinalizada como rota para a Terra de mel. Brasileiro, português, entre os dois, na ponta do abismo de onde espreitam o mundo, eis o lugar ali arquitetado. Aquele som inspirou a questão feita à época do lançamento do disco: “Da caldeirada surgiu um disco sem dúvida bonito. Mas será um disco de música portuguesa?"19 Eugénia não titubearia em responder: “Não, é um disco feito no que de bom se pode tirar da junção do que eu sei fazer com o que eles sabem fazer. E de que eu gosto muito".$^{20}$

O que se sente das audições do álbum de estreia de Eugénia Melo e Castro reverbera em sua fala sobre os bastidores da gravação:

\footnotetext{
${ }^{15}$ DUARTE, António. Geninha: entre o sol e a paixão. Se7e, Lisboa, 3 fev. 1982, p. 3.

16 "Cais" (Yório Gonçalves e Eugénia Melo e Castro), Eugénia Melo e Castro. LP Terra de mel, Polygram, 1982.

17 "Começo de mar" (Yório Gonçalves e Eugénia Melo e Castro), Eugénia Melo e Castro, op. cit.

${ }^{18}$ CERTEAU, Michel de. A invenção do cotidiano: artes de fazer. Petrópolis: Vozes, 1994, p. 214.

${ }^{19}$ COSTA, Belino. Eugénia Melo e Castro: Terra de mel só existe na minha cabeça. Se7e, Lisboa, 3 fev. 1982, p. 12.

${ }^{20}$ MELO E CASTRO, Eugénia apud COSTA, Belino, op. cit., p. 12.
} 
Terra de mel foi gravado ao vivo dentro do estúdio. O horário que nos deram foi de meia noite às oito da manhã. Oito dias seguidos. Sem técnico. O técnico deixava a mesa preparada e deixava lá um assistente que, obviamente, passada uma hora, já estava a roncar num canto. Quem fazia o som era o Wagner de um lado e eu do outro. E foi complicado por isso. Mas o ambiente que se viveu foi espetacular! E o Kleiton, nessa altura, também veio. E foi sensacional. Não havia aposta alguma de nenhuma gravadora. Eu fui ter com a Polygram nessa época e disse: "Eu quero gravar um disco...". "Ah, então, se trouxer o Wagner Tiso, a gente arranja-te o estúdio." Aí, eu disse: "Tudo bem". Eu fui para o Brasil, trouxe o Wagner Tiso, trouxe o Kleiton, e então eles já nos arranjaram esse estúdio. Aí o Wagner disse: "É isso que temos, então vamos trabalhar com o que temos". Durante o dia dormia, uma parte do dia passava as partituras, fazia os arranjos, depois já entrava em estúdio, levava uma comida... estamos em maio, junho de 81. Aí eles [os músicos] foram embora, e eu só consegui por voz em setembro, outubro. Porque nunca mais voltei a ter estúdio, porque eu não consegui fazer as gravações de todas as bases, os arranjos todos, os complementos todos do Wagner e de todos os músicos. E o disco ficou por mixar e ficou sem voz, só com voz guia. Aí eu fiquei sozinha para por a voz. Eu pus a voz sozinha! E ninguém da editora lá ia, não queriam nem saber o que que eu estava a fazer e tal. Nem contrato tinha, não tinha absolutamente nada. Só fiz contrato depois do disco ter estourado. Fui eu que fiz a capa, fui chamar o gráfico, que era meu amigo João Melo, e depois fui chamar o fotógrafo, o Silveira Ramos. Apresentei o produto pronto. E eu que mixei. O Wagner, ao ouvir a mixagem: "Não, aqui já era para ter acabado!" "Fiz como eu achei, eu adoro esses finais longos". Foi tudo isso, essa vontade de fazer e de ir absolutamente pelo instinto que deu essa preciosidade que é o Terra de mel. Quer dizer que é um disco completamente diferente de tudo. E que veio como uma lufada de ar fresco. ${ }^{21}$

A desatenção da gravadora em relação ao Terra de mel se converteu em espaço para a liberdade daqueles artistas. O que poderia ser uma limitação foi tomado como meio de deixar fruir a criatividade. O clima espontâneo daquelas gravações também se estabeleceu favorecido pelo tipo de diálogo estabelecido. As pessoas envolvidas no projeto eram artistas com que Eugénia trocou ideias em suas andanças pelo meio musical. Dessa circulação nasceriam amizades, parcerias e misturas sonoras que dariam colorações distintas àquele álbum. Esses vínculos deixam entrever uma socialidade, "essa espécie de empatia comunalizada". 22 Wagner Tiso conta em entrevista ao Se7e que passou um mês em contato com Eugénia em Lisboa, o que permitiu o envolvimento e o entrosamento naquele trabalho. ${ }^{23}$ Fomentava-se, assim, uma amizade e mesmo uma dicção interna, própria dos que se identificam e partilham vivências. Eugénia nos conta, por exemplo, que o título da canção "Beco do Tiso", expressão que logo nos remete à paisagem mineira e ao universo simbólico clube-esquinista - um exemplo seria a canção "Beco do Mota", de Milton Nascimento e Fernando Brant -, vem de um canto de Lisboa: "A gente não tinha título para a música. E tem um beco ao lado da minha casa que o Wagner adorava. Ia para ali com uma garrafa, era verão. Tudo acontecia, aquela gente sempre a passar, e o Wagner montava ali uma cadeirinha, uma garrafinha de

\footnotetext{
${ }^{21}$ Eugénia Melo e Castro em entrevista concedida ao autor, op. cit.

${ }^{22}$ MAFESOLLI, Michel. O conhecimento comum: introdução à sociologia compreensiva. Porto Alegre: Sulina, 2007, p. 198.

${ }^{23}$ Cf. DUARTE, Pedro, op. cit., p.16.
} 
vinho, uma mesinha, e ficávamos ali. E virou o Beco do Tiso. E quando a gente não tinha nome para a música: “Ah, Beco do Tiso!”24

Experiências como esta criaram uma espécie de cumplicidade que acabou por dar consistência à obra daqueles artistas. Ali estavam partilhando um trabalho, burilando peças, buscando a identificação e o espanto: diálogo. $\mathrm{Na}$ verdade, a casa de Eugénia, que, além de cantora, é ainda filha da escritora Maria Alberta Menéres, tornou-se ponto de encontro e abrigo para músicos. E nas andanças pelo meio artístico, muitos contatos eram estabelecidos. Antes de se aventurar a gravar discos, a cantora-compositora já havia participado de coros de artistas já mais experientes do cenário português, tais como Sérgio Godinho, Fausto e Júlio Pereira, também interessados em novas linguagens e toadas para a música portuguesa.

As idas e vindas de artistas brasileiros a Portugal ampliariam esses encontros. Na entrevista que citamos, de Wagner Tiso, recorda-se o sucesso que foi uma participação improvisada no show do grupo português Trovante na Festa do Se7e - 1981. Naquela ocasião, partiriam do Brasil atrações como Joyce e Paulinho da Viola. Nos bastidores dos espetáculos, iam-se armando redes. A respeito do entrosamento entre Wagner e o Trovante, se destacaria:

O senhor Wagner Tiso, tecladista de Milton Nascimento e um dos maiores músicos do Brasil - presente em Lisboa, onde gravou um LP com Eugénia Melo e Castro -, acabaria por aceder ao convite dos Trovante para uma "perninha" de improvisação ao acordeão, em palco, o que seria uma prova cabal da qualidade desse grupo. Não exageremos se dissermos que o momento musical que reuniu os Trovante com Wagner Tiso foi o mais emocionante e espetacular da festa do "Se7e". [...] Na assistência dançava-se ao bom estilo folclore português e no palco os Trovante quebraram barreiras, fazendo "virar" a multidão do Rock, captando-a para uma música repleta de emoções, uma música absoluta, sem rótulos, que vive da paixão pelas coisas simples. ${ }^{25}$

É interessante notar que naquele instante o nome de Wagner Tiso reverberava pela cena portuguesa pela sua parceria bem-sucedida com Milton Nascimento e pelo trabalho recente com Eugénia Melo e Castro. Logo os críticos ficariam atentos a outros nomes, como o de Novelli, compositor e instrumentista pernambucano que se tornou conhecido pelo envolvimento com o trabalho de Milton Nascimento em álbuns célebres da década de 70 e que assinaria, juntamente com Wagner Tiso e Eugénia Melo e Castro, a composição que daria título ao segundo disco da cantora-compositora: Águas de todo o ano. ${ }^{26} \mathrm{O}$ disco, gravado e lançado no Brasil, contou com um time de grandes instrumentistas - tais como Ricardo Silveira (guitarra), Luiz Alves (baixo), Mauro Senise (sopros), Paulinho Braga e Robertinho Silva (bateria e percussão), Tunai, Vinicius Cantuária e Kleiton Ramil (Violão) -, num clima de pura descontração, onde se renovava a parceria com Wagner Tiso (piano, órgão, arranjos e direção musical) e incrementavam-se diálogos através de novos encontros e participações especiais, tais como a de Ney Matogrosso.

\footnotetext{
${ }^{24}$ Eugénia Melo e Castro em entrevista concedida ao autor, op. cit.

${ }^{25}$ Trovante e Sérgio Godinho vencedores numa festa sem vencidos. Se7e, Lisboa, 15 jul.1981, p. 3.

${ }^{26}$ Cf. GOBERN, João. Novelli, o músico-sombra de Milton e Chico. Se7e, Lisboa, 25 jan. 1984.
} 
Em passagem por Lisboa naquele mesmo ano de 1982 para segundo show na cidade, Milton Nascimento revelaria o desejo de realizar trabalhos com artistas que conheceu em Portugal: Eugénia Melo e Castro e Sérgio Godinho. Com esse último, comporia, inclusive, uma canção que sairia no disco Coincidências, lançado pelo cantor-compositor português em 1983. O disco contou com parcerias estabelecidas com nomes importantes da música brasileira, tais como o próprio Milton Nascimento, Chico Buarque, João Bosco, Ivan Lins e Novelli. "Coincidências" também sinalizava para linguagens contemporâneas, flertando com gêneros como o jazz.

Em 1983, o semanário Se7e cobriria mais uma viagem de Milton Nascimento a Lisboa. Mas, ao contrário do que se esperava, dessa vez o artista brasileiro tinha aterrissado em terras lusitanas apenas para rever amigos e parceiros musicais. Nada de shows, a não ser como mais um membro da plateia de Sérgio Godinho. Em companhia da reportagem do Se7e e de uma trupe de artistas luso-brasileiros, Milton visitaria o Mosteiro dos Jerónimos, de onde falaria de seu encontro com a música portuguesa:

\begin{abstract}
Abandonamos o primeiro sector e, num pátio interior dos Jerónimos, falamos do mar que nos separa... "Bom, tanto mar é só no avião! Na música, vamos andando bem, o intercâmbio é possivel e desejável." Com alguma emoção confessa que só à tarde irá ouvir, pela primeira vez, a composição que escreveu a meias com Sérgio Godinho para o álbum Coincidências ["A barca dos amantes"]... "Ele deu-me a letra, lindíssima, e eu fiz a música mais bonita que consegui. Acho que deve ser uma bela canção". Da música portuguesa, que há um ano pouco conhecia, diz agora estar já dentro dela: "Podemos fazer muitas coisas juntos, o que conheço é bom mesmo!" Olha para Eugénia Melo e Castro, abraça-a... "Eu propus uma canção para ela, e ela gravou"... Eugénia: "Eu ouvi, adorei e aceitei". ${ }^{27}$
\end{abstract}

Nessa rede de contatos e de trocas, elabora-se um trabalho fundado na diversidade musical, compartilhamento de referências e, igualmente, um esforço por realizar músicas que ultrapassassem fronteiras, que sinalizassem para sonoridades que traduzissem a atualidade através de uma linguagem em diálogo com o seu tempo. Para isso era importante superar rótulos musicais, alguns relacionados à própria música portuguesa ${ }^{28}$, praticamente desconhecida, em sua variedade, no Brasil daquela época. Numa entrevista, Wagner Tiso refletiria sobre essa questão ao relatar a experiência de gravação com Eugénia Melo e Castro: "Eu vim trabalhar com a Geninha, como uma nova experiência, e adorei. Sem querer, fizemos uma aproximação entre o Brasil e Portugal. Agora, é preciso incrementar essa relação - aos poucos, os brasileiros vão conhecendo a música portuguesa e vão esquecendo aquela imagem antiquada que eles têm de vocês". ${ }^{29}$

Nessa mesma época, o Se7e cobria uma viagem do Trovante ao Brasil. Mereceu destaque a fala de Luís Represas, integrante do grupo, que afirmaria

${ }^{27}$ DUARTE, Pedro. Milton Nascimento em Lisboa: “vim ver os meus amigos". Se7e, Lisboa, 29 jun. 1983, p. 23.

${ }^{28}$ Ver GUERRA, Paula. Um lugar sem lugar... no rock português. Outros Tempos, v. 17, n. 29, São Luís, 2020.

${ }^{29}$ TISO, Wagner apud DUARTE, Pedro, op. cit., p. 16. 
à plateia brasileira: "Estamos aqui também para desfazer um equívoco e dizervos que a música portuguesa não é só fado, vira ou Roberto Leal. Quero mesmo acrescentar que o Roberto Leal é praticamente desconhecido em Portugal" $^{30}$

Mas que esperar de um cantor português em terras brasileiras? A resposta entremeia o alerta emitido por Luís Represas: do cantor português, espera-se, de imediato, que interprete fado, simplesmente. Ora, tratava-se de um gênero que soava quase como antiquado para quem ansiava por novas linguagens que pudessem melhor traduzir o tempo presente. Sem contar que aquela é uma postura que carrega um tom reducionista, ante a variedade de estilos presentes na música portuguesa, fenômeno, infelizmente, recorrente em qualquer cultura. ${ }^{31}$ Entretanto, a solução não seria romper com o fado, mas, antes, desviar-se do estigma normalmente colado aos nomes dos artistas quando planavam sobre outras localidades, onde a expectativa, quando não recaía sobre o fado, deslizava para o cancioneiro popular por meio de cantigas conhecidas de manifestações folclóricas. Eugénia Melo e Castro recorda o peso desses estereótipos em suas primeiras idas ao Brasil. Seu desejo era ser uma cantora portuguesa contemporânea no Brasil, e assim, volta e meia, a artista tinha que se esquivar do fado para dar asas à própria música que fazia:

Eu tive que me bater contra o fado, que era uma coisa que não me passava pela cabeça. Porque eu chegava ao Brasil, entrava num espetáculo qualquer, num programa de televisão, num programa de rádio, e sempre apresentavam: "E agora a fadista". "Eu não sou fadista." "Mas canta "Foi Deus"!" "Eu não canto "Foi Deus", eu não canto "Nem às paredes confesso", eu não sei isso. Eu posso cantar o "Cais", eu posso cantar uma música portuguesa do Sérgio ou do Jorge Palma. Existem jovens compositores em Portugal, existem pessoas fantásticas. Mas não peçam para cantar fado, eu não tenho alma fadista. Não faz parte de minha alma interna. ${ }^{32}$

Sua música passaria longe do circuito onde a canção portuguesa era celebrada no Brasil, tal como o das casas dedicadas às colônias de imigrantes portugueses, onde o que interessava mesmo era o fado. A canção de Eugénia circulou, e circula, nos meios alternativos, nos espaços dedicados à MPB, seja através de apresentações solo ou de projetos coletivos. O componente portu-

\footnotetext{
${ }^{30}$ REPRESAS, Luís apud COSTA, Belino. O Trovante no Rio de Janeiro. Brasileiros já sabem: Portugal não é só fado. Se7e, Lisboa, 15 maio 1982, p. 13.

${ }^{31}$ A esse respeito é interessante o depoimento de Sérgio Godinho no livro Cantores de abril, quando se recorda de suas primeiras experiências musicais: “O Zeca e o Adriano tinham-me dado um abanão enorme porque eu não era grande apreciador da música portuguesa. Curiosamente achava piada a coisas mais antigas, ao conjunto do António Mafra, à Amália Rodrigues. O Zeca, de repente, aparece com um tipo de atitude diferente, a música libertando-se do estigma do fado de Coimbra, um novo estilo a que fui muito sensível, e nessa altura compus umas coisas que soavam Zeca. Era um apaixonado do Zeca." GODINHO, Sérgio apud RAPOSO, Eduardo M. Cantores de abril: entrevistas a cantores e outros protagonistas do "Canto de intervenção". 2 ed. Lisboa: 2014, p. 230. Na mesma entrevista, Sérgio Godinho fala da limitação de algumas nomenclaturas para a compreensão de sua arte em Portugal, como a de "canto de intervenção" quer dizer, de protesto -, expressão utilizada para dar sentido à música de cantores-compositores que se colocaram contra o salazarismo. Para ele, "Eu nunca respondi muito por essa designação. Sobretudo, comecei a achar que era extremamente redutora em relação àquilo que eu faço e ao que me interessa tocar. Canções que são sobre reflexões filosóficas, vivenciais, sobre a maneira de estar, sobre o amor, sobre a sociedade. Um olhar sobre o social. Lembro-me quando se começou a arrumar os cantores na prateleira, numa altura em que era como se do Zeca só se conhecesse a 'Grândola'”. Idem, ibidem, p. 231.

${ }^{32}$ Eugénia Melo e Castro em entrevista concedida ao autor, op. cit.
} 
guês de seu trabalho é a própria voz, a pronúncia em português lusitano, da qual nunca abriu mão. Abre-se, a partir daí, uma nova perspectiva para o conteúdo de canções de vários compositores brasileiros. Através de dobras e acentos, o canto de Eugénia destaca essa ou outra palavra, quando ouvida por um brasileiro, ou seja, pela forma de cantar e emitir cada nota, a cantoracompositora oferece novas leituras para aquelas canções.

A artista, que se viu obrigada a recusar o rótulo de fadista, preferindo pugnar pelo despertar de um novo tempo da música portuguesa, que, em suma, é o tempo da própria artista, teria encontrado seu lugar de fala justamente numa fronteira musical entre vários gêneros, onde o experimentalismo é a tônica do trabalho e as fronteiras geográficas se convertem em pontes para expressivas trocas musicais. Evidentemente, rótulos e estigmas não se limitam a um patamar definido. Num meio onde o enquadramento é ferramenta de divulgação, seja através de críticas de discos ou de catálogos de gravadoras, o enfrentamento se faz constante para os que desafiam o processo de rotulação. Nisso, o trabalho de Eugénia Melo e Castro e de muitos portugueses se avizinhava do de seus parceiros brasileiros. Na verdade, ao longo dessas linhas, assistimos todo o tempo à aproximação entre artistas que compartilhavam referências e posturas e ansiavam mais por descobrir novos percursos por onde se expressar do que por se autodefinir. Isso faz recordar o depoimento de Milton Nascimento sobre o álbum Native dancer, gravado com Wayne Shorter em 1974. Em entrevista a mim concedida, o cantor-compositor relatou:

Tinha uma coisa, que todo mundo me perguntava que tipo de música eu fazia. Eu nunca soube, nem queria saber. Aí eu sempre falava: "Não sei". "É samba?". "Não, não é samba, mas tem alguma coisa de samba." "É isso?". "Não". "É jazz?". "Não". Aquele negócio todo. Agora, a cabeça do Wayne é uma cabeça assim, digamos, eu acho que é, ou quase, ou igual à minha. Então, ele chamou o Herbie [Hancock] para tocar no disco, tinha nós três do Brasil [Milton Nascimento, Wagner Tiso e Robertinho Silva], chamou um baixista da área pop, um guitarrista da América Central, e o Airto Moreira também, o engenheiro de som era produtor do The Band, que costumavam tocar com o Bob Dylan. E chamou, para produzir o disco, o Jim Price, que naquela época era produtor do Rolling Stones. Aquilo foi uma feijoada misturada com sei lá o quê [risos], uma confusão danada. E o disco saiu, e aconteceu até uma coisa maravilhosa, assim, porque geralmente as pessoas que gostam de jazz não gostavam do pop, quem gosta do rock não gosta disso e tal. Esse disco acabou com tudo isso. Inclusive, quando o disco saiu, o pessoal de várias áreas começou a me procurar. E o disco é uma coisa tão forte, que ele é atemporal. Então, até hoje tem gente que pensa que a gente gravou anteontem. Mas ninguém mais perguntou que tipo de música era [risos]. ${ }^{33}$

Desafiar limites, brincando, movendo e misturando informações sonoras de diferentes campos num mesmo lugar, eis o que temos. Nesse exercício, abre-se brecha para "cavar o impensado do próprio pensamento, fazendo-o deslocar" 34 , deixando vir à tona o diferente, a novidade. Esse mesmo espírito inspira as aventuras sonoras de Eugénia Melo e Castro. Em Terra de mel, por

\footnotetext{
33 Milton Nascimento em entrevista concedida ao autor. Rio de Janeiro, 17 jul. 2012. A entrevista foi registrada por Mayara Andrade de Carvalho Pacheco.

${ }^{34}$ SILVA, Leandro Mendanha e. Nas transversais do tempo: uma intervenção de Foucault na História e sua apropriação pela historiografia. Dissertação (Mestrado em História) - UnB, Brasília, 2009, p. 73.
} 
exemplo, buscava afinar-se com aquela sonoridade produzida por Wagner Tiso e, ao mesmo tempo, imprimir novas tonalidades, promover diálogos com outros gêneros. Nessa levada, produzem-se obras que escapam aos enquadramentos, o que pode ser solução em termos de dar vazão à criatividade, mas também problema, quando se pensa nos meandros da divulgação. No entanto, estamos diante de artistas ariscos, que buscam por meios-termos para deixar fruir a liberdade. Ou seja, cavam brechas diante de cenários onde prevalece a música de feição meramente comercial. A esse respeito, chama a atenção a matéria do Se7e por ocasião da segunda viagem de Milton Nascimento a Lisboa:

Este país só vive tendo um ídolo, um padrão, um modelo. E estão querendo pôr o Milton lá. O trono está prontinho p'ra ele sentar". As palavras são de Luís Gonzaga Jr. e retratam bem a situação. Querem transformar Milton num herói, inventar um novo rei, mas ele próprio confessa preferir a margem, a sombra: "Está ficando cada vez mais difícil entrar num palco. E cada vez mais emocionante também. Porque cada vez o olho, sabe, o olho deles, a plateia, está maior. E eu penso, se eu estivesse na plateia e não no palco, o que estaria sentindo, o que estaria querendo? Explicação eu não tenho. Não tenho mesmo. Eu só sei que não mudei, continuo indo sempre para onde sempre fui, fazendo a minha música. Só sei que não vou aceitar ser líder de ninguém, nem ser estrela. A saída é eu continuar a fazer as coisas, a música, de dentro da gente. De dentro da vida e do momento da gente. ${ }^{35}$

O artista adota uma conduta coerente com a sua poética: todo o trabalho de Milton Nascimento é sempre novidadeiro, com algum componente inédito a injetar frescor e espanto em suas composições. Nada parece planejado, mas antes construído mediante afinidades musicais com outros artistas, que, de alguma forma, atualizam a história do próprio Milton. Cada detalhe é por ele reverenciado, tudo tem o seu lugar, nada é mero enfeite. Então, como se arrogar o status de líder daquilo que nasce coletivo?

Num percurso construído por parcerias e trocas musicais, se identificaria com outros nomes sintonizados com esse ideal, como o compositor Novelli, músico de extrema importância na carreira de Milton, que assim se expressou quando passou por Lisboa:

Eu nunca abdiquei dos meus projectos pessoais mas há uma enorme dificuldade para conseguir gravar no Brasil um tipo de música descomprometida com o êxito como é a minha. E eu não quero ser um compositor condicionado, nunca me sento ao piano propositadamente para compor isso ou aquilo. Em resumo, não me despersonalizo. Também reconheço que só um ou dois conseguem viver e sobreviver, não cedendo nunca aos desejos das multinacionais - esses são os casos de Chico e Milton. ${ }^{36}$

Do que afirma Novelli, podemos refletir que, se, por um lado, o interesse em realizar uma música gestada em linguagens experimentalistas aproximava os artistas que aqui elencamos, tanto do cenário brasileiro como do lusitano, ampliando-lhes os horizontes, por outro lado, tal investimento impli-

\footnotetext{
${ }^{35}$ COSTA, Belino. Milton Nascimento: “estava doido por voltar!”. Se7e, Lisboa, 7 jul. 1982, p. 15.

${ }^{36}$ Novelli apud GOBERN, João, op. cit., p. 17.
} 
caria um confronto com as exigências do mercado. Em suma, tratava-se de uma grande ousadia.

Interessante notar que boa parte deles tiveram no jazz uma referência e inspiração. De alguma forma, o gênero que virou sinônimo de liberdade é apropriado e ressignificado por esses artistas transgressores de padrões estéticos. O gosto pela transformação e inovação dá a ver a própria inquietude. Tal movimentação nos faz recorrer à figura do pensador-artista nômade esboçada pela pesquisadora Negrão de Mello: "Diferentemente do sedentário, portanto, o pensador-artista nômade recusa a mera recognição e reivindica outro estatuto para as representações que constrói, pois é justamente em seu nomadismo que encontra o vetor que o impulsiona a agir e ousar, em constante movimento de ruptura com modelos pré-estabelecidos. O fio condutor para tal performance convida a pensar na arte como a feiticeira salvadora". ${ }^{37}$

A música que se esgueira dos padrões torna-se, por óbvio, de difícil classificação. A obra de arte assim se faz como lugar de expressão e questionamentos tanto dos padrões estéticos quanto das questões que envolvem o cotidiano e as temporalidades nas quais estão inseridos e, por que não, das fronteiras que demarcam limites, que se asseveram em reivindicações de cunho nacionalista. Como percebemos, as linhas que estabelecem o diálogo desses artistas luso-brasileiros ultrapassam todos os índices nacionais aguardados. Não se trata apenas de misturar culturas brasileira e portuguesa, mas também de compartilhar um sentimento de pertença a uma cultura global e ao tempo que se vive. Para esses artistas, mais do que enquadrar, é necessário atravessar, romper, alargar fronteiras ou simplesmente, navegar, como sugere a canção "A barca dos amantes":

Ah, quanto eu queria navegar
Pra sempre a barca dos amantes
Onde o que sei deixei de ser
Onde ao que eu vou não ia dantes

Ah, quanto eu queria conseguir trazer a barca à madrugada

E desfraldar o pano branco

Na que for terra, a mais amada

E que em toda a parte

O teu corpo

Seja o meu porta-estandarte

Plantado no seu mais fundo

Posso agitar-me no vento e mostrar a cor ao mundo

Ah quanto eu queria navegar

Pra sempre a barca dos amantes

\footnotetext{
${ }^{37}$ NEGRÃO DE MELLO, Maria Thereza. Nas terras do sol: Brasil e Cuba nas representações de Glauber Rocha. In: CABRERA, Olga e ALMEIDA, Jaime (orgs.). Caribe, sintonias e dissonâncias. Goiânia: Cecab 2004, p. 66. A esse respeito ainda podemos citar as reflexões de Maffesoli sobre a figura do nômade: "É seu escapismo, essa capacidade de se movimentar, que o predispõe toda hora à sublevação, aos transbordamentos afetivos, à quebra da ordem estabelecida. O errante não perdeu nada em sua propensão ao movimento, até faz disso sua cultura, e isso é intolerável quando prevalecem os valores estabelecidos". MAFFESOLI, Michel. Sobre o nomadismo: vagabundagens pós-modernas. Rio de Janeiro: Record, 2001, p. 44.
} 
Ah, quanto eu queria a navegar

Fazer a trança à calmaria

Avistar terra e não saber

Se ainda o é quando for dia.

"A barca dos amantes", parceria de Milton Nascimento e Sérgio Godinho, também foi gravada pelo cantor-compositor brasileiro em álbum homônimo registrado ao vivo e lançado em $1986 .{ }^{38}$ A ambiência sonora delicada abre horizontes por onde a voz de Milton Nascimento plana em voo calmo, convidando a atenção para a sensibilidade daqueles versos de amor. Ali o sentimento é estrada pavimentada por descobertas, metáfora para o movimento de se conhecer e se ampliar, seja nas relações afetivas, sociais e coletivas, ou mesmo artísticas. Tudo recorda deslocamento. E quando a voz sobe, cobrindose de falsetes, suspendem-se os limites, emoldurando-se assim as travessias.

É nesse lugar de encontro que as vozes de tantos artistas brasileiros e portugueses se irmanam. Às vezes as notícias desses encontros apenas ecoam distantes, como centelhas de canto robusto, e ganham força quando as buscamos na sombra. Enveredar pelos arquivos dos jornais portugueses e realizar entrevistas com personagens imersos nessa história é um exercício que amplia o âmbito da historiografia musical, pelos diálogos entre incontáveis partícipes de um projeto que transcende nomenclaturas e rubricas. Debruçar-se sobre tais diálogos é vivenciar e experimentar, de novo e sempre, o sonho de uma música de coloração luso-brasileira-múndi, numa perspectiva de um trabalho sempre em construção.

Artigo recebido em 15 de julho de 2020. Aprovado em 10 de setembro de 2020.

\footnotetext{
38 "Barca dos amantes" (Milton Nascimento e Sérgio Godinho). Milton Nascimento. LP A barca dos amantes. Barclay, 1986.
} 